\title{
Trajetória individual, imaginação e narrativa - três questóes provocadoras e sugestivas em Como Shakespeare se tornou Shakespeare
}

\author{
Henrique Buarque de Gusmão \\ Universidade Federal do Rio de Janeiro \\ Rio de Janeiro, RJ, Brasil \\ henrique_gusmao@yahoo.com.br
}

Greenblatt, Stephen. Como Shakespeare se tornou Shakespeare. Tradução de Donaldson M. Garschagen e Renata Guerra. São Paulo: Companhia das Letras, 2011.

Como Shakespeare se tornou Shakespeare, de Stephen Greenblatt, pode ser uma leitura ao mesmo tempo provocadora e sugestiva para historiadores. Proponho, nesta resenha, uma apresentação de três eixos de questóes - ou três elementos da análise de Greenblatt - que percorrem todo o livro e que me parecem inquietantes e propositivos para a produção historiográfica contemporânea.

O primeiro deles é a forma como Greenblatt aborda a trajetória individual do célebre dramaturgo inglês. No prefácio do livro, o autor apresenta seus objetivos gerais. $\mathrm{O}$ principal deles é percorrer os caminhos que levam da vida de Shakespeare à sua obra. Tal objetivo busca superar uma sensação recorrente de leitores e analistas da obra shakespeariana: a de que suas peças e sonetos resistem a explicaçóes, tendo sido escritas por uma espécie de deus a-histórico e absolutamente genial.

Para escapar dessa imagem mitológica de Shakespeare e de sua produção, Greenblatt reconstrói múltiplas relaçóes que o dramaturgo teria estabelecido em seu espaço social, sendo ele percebido como um escritor extremamente aberto para o mundo - dimensão esta que está presente no título original em inglês: Will in the world. São levados em conta, neste trabalho de reconstrução de uma trajetória individual, os livros que o dramaturgo teria lido; ordinárias questôes de seu dia a dia; o preço do papel em sua época; o ambiente das reformas religiosas, que náo poderia ter esca- pado a Shakespeare; encontros possíveis do autor com rebeldes católicos, como Edmund Campion. Lançando mão desses táo distintos elementos de análise, Greenblatt realiza um dinâmico jogo em que se entrelaçam açóes de Estado ou da Igreja e sutis estratégias individuais.

Esta reconstrução das múltiplas relaçôes estabelecidas por Shakespeare é realizada, principalmente, para a compreensão de uma dimensão bastante delicada na análise da vida de um artista: o momento de sua criaçáo. Greenblatt analisa as condiçôes em que Shakespeare escreve suas peças percebendo como funcionava o mundo das diversóes e do teatro no qual ele se insere. Logo nos primeiros capítulos do livro são discutidas as moralidades (gênero teatral medieval didático que apresentava de maneira alegórica virtudes e vícios) que o dramaturgo teria assistido em sua adolescência e que alicerçam suas primeiras referências teatrais. Também são estudados testamentos de pessoas ligadas a teatro e orçamentos de companhias como forma de se compreender as condiçóes financeiras a partir das quais as peças eram encenadas. No capítulo 6 (A vida nos subúrbios), Greenblatt aprofunda-se na compreensão do ambiente teatral a partir do qual Shakespeare cria suas peças, analisando mais detidamente o mundo das diversôes nos subúrbios londrinos. Estes primeiros anos de Shakespeare em Londres são abordados como momentos de profundas transformaçôes no mundo teatral: com o crescimento urbano e com a sedentarizaçáo dos teatros, muitos escritores passam a produzir em torno de vinte peças por ano. Ficam postas, então, circunstâncias institucionais que criam um mercado de teatro e de escritores 
de teatro analisados mais de perto no capítulo 7 (Shakespeare sacode a cena).

O círculo de escritores de Londres do final do século XVI é analisado com muita minúcia por Greenblatt nesse capítulo 7, e a produção de Shakespeare é pensada a partir das relaçôes que ele estabelece dentro desse círculo. A começar por suas primeiras peças, como Henrique VI, que é analisada a partir de sua relação com um texto de um dos escritores mais marcantes para Shakespeare: o Tamerläo, de Christopher Marlowe. Greenblatt busca entender tanto a identidade deste círculo de escritores, marcada pela valorização da escolaridade e do perigo, como a forma como Shakespeare nele se insere - certamente de uma maneira muito específica, podendo trabalhar com um estilo mais livre, fugindo do exibicionismo acadêmico e muitas vezes sendo malvisto por isso.

Chama a atenção, na análise de Greenblatt, a constante preocupação em se pensar a produção dramatúrgica a partir dos modelos teatrais que circulavam naquele ambiente. Escritores, obras, espaço teatral, público são colocados em complexas redes de relaçóes que possuem lógicas próprias, a partir das quais se pode entender uma produção como a de Shakespeare. Essa compreensão relacional da produção e da recepção também se dá na análise de seus sonetos, realizada no capítulo 8 (Senhor-senhora).

É a partir destas lógicas e deste emaranhado de relaçóes que Greenblatt pensa a criação de alguns personagens shakespearianos. Falstaff é um dos personagens aos quais Greenblatt dedica algumas páginas de seu livro. Ele é o resultado dos duros embates entre Shakespeare e o escritor Robert Greene. Falstaff representa o tipo bufão, empolado, bêbado, como diversos dos "gênios universitários" que conviveram com Shakespeare. Greenblatt, entretanto, toma o cuidado de não tratar este personagem como um reflexo direto de pessoas que Shakespeare conheceu. Se Falstaff incorpora diversos traços da personalidade de Greene, ele é também um antigo personagem de uma peça anônima. Desta forma, a criação dos personagens é pensada a partir do uso de múltiplas fontes, tendo o dramaturgo a capacidade de reimaginar seu mundo, invertê-lo muitas vezes, embaralhá-lo, disfarçá-lo e, de maneira inesperada, criar personagens com tal princípio interior que geram a sensação de existirem fora das páginas da peça.

Há aí uma dimensão da análise de Greenblatt que merece ser destacada: a valorização que ele confere à habilidade específica de Shakespeare. Se seu livro, por um lado, vai na direção de historicizar a produção shakespeariana e reconstruir redes de relaçóes nas quais ela se inseria, por outro lado ele não negligencia um dado misterioso da produção estética: a capacidade individual do artista. E a maior habilidade de Shakespeare parece ter sido a de criar personagens com fortes e complexos princípios individuais. Já no contato que ele teve com as moralidades medievais na adolescência, teria percebido que aquelas tramas funcionariam melhor com personagens específicos do que com suas abstraçóes personificadas e alegorias. O capítulo 10 (Falando com os mortos) apresenta o caso mais emblemático deste tipo de personagem criado por Shakespeare: Hamlet. Greenblatt analisa as diversas operaçóes que Shakespeare realizou na antiga e conhecida história do príncipe Hamlet para atingir seu objetivo, como a criação do fantasma do pai, que não existia na história original e que adéqua a trama para a vivência que ele quis criar para o protagonista, carregada de introspecçáo e nebulosidade. Da mesma forma, também são analisadas as criaçôes dos personagens Iago, Lear e Macbeth.

Ainda em relação à análise da trajetória individual de Shakespeare, outra operação analítica levada adiante por Greenblatt - e esta, certamente, mais controversa - deve ser destacada. Trata-se da busca de elementos da vida do dramaturgo e de seus posicionamentos a partir de suas peças. $\mathrm{Di}$ versos exemplos podem ser citados. Já no início do livro, Greenblatt busca, a partir das primeiras peças de Shakespeare, entender como teria se dado sua alfabetização. $\mathrm{Ou}$, a partir das inúmeras e precisas referências que as peças trazem sobre o couro, busca comprovar que seu autor trabalhou com o pai no fabrico de luvas. Mais adiante, busca encontrar, nas peças, indícios de deboche ao homem 
que o teria expulsado de sua cidade natal. Encontra poucos, refuta tantos outros. Aborda com mais segurança um jogo de palavras presente em um de seus sonetos que pode ser encarado como uma ironia em relação à sua mulher. Finalmente, nos capítulos finais, ao analisar as peças $A$ tempestade e Rei Lear, Greenblatt faz um longo levantamento de diferentes representaçóes da aposentadoria utilizadas por seus personagens e especula sobre qual seria a visão de velhice e recolhimento com a qual Shakespeare compartilhava. Desta forma, ao longo de todo o livro, está presente um tipo de análise que busca elencar e entender representaçóes dos mais diferentes posicionamentos em relação a variados temas, e procura encontrar aquela que teria sido defendida pelo dramaturgo. É como se o analista buscasse encontrar, nas tantas falas dos personagens, aquelas que poderiam ter sido pronunciadas pelo próprio Shakespeare em diferentes momentos de sua vida.

Esta operação é realizada, entretanto, com o cuidado de quem percebe as armadilhas intelectuais nas quais se pode cair. Em diferentes momentos, Greenblatt lembra a seus leitores que a arte não é algo que emerge diretamente da vida e que sua análise não parte desse pressuposto. Para confirmar isso, ele atenta para o fato de que, em diferentes peças de Shakespeare, há ácidos deboches voltados para algumas atitudes que, certamente, eram muito valorizadas pelo dramaturgo - como a sua vontade de atingir a condição de cavalheiro. Se suas peças, por um lado, expressam opiniôes e pontos de vista que foram defendidos por ele em algum momento de sua vida, por outro lado, elas também ironizam atividades que ele levava muito a sério. Elas portam expectativas estranhas àquelas que ele nutria, são fruto de uma imaginação certamente muito rica, que se distanciava, em alguns momentos, de seu cotidiano. Greenblatt percebe neste procedimento literário uma atitude estratégica de Shakespeare, que preferia adotar uma postura discreta em seus textos num momento em que as cabeças de rebeldes mortos eram expostas em plena cidade de Londres. O livro refuta, entâo, uma série de relaçôes diretas que poderiam ser apontadas entre os textos shakespearianos e a personalidade do dramaturgo. $\mathrm{O}$ fato de Hamlet apresentar um personagem fantasmático, que parece viver no purgatório, não necessariamente revela um dado das convicçóes religiosas do autor. Como sugere Greenblatt, a peça não busca ser uma aula de teologia. Ao longo da análise, fica sempre apontado que não há vínculos óbvios entre os textos e a vida de Shakespeare.

No entanto, isso não impede que Greenblatt busque vínculos mais sutis entre a obra do dramaturgo e suas vivências. Chamo a atenção para duas de suas análises. A primeira diz respeito à análise da temática do casamento. Quando trata do casamento de Shakespeare, Greenblatt busca entender a forma como o amor era representado no teatro elisabetano - comparando essa representação, inclusive, com posteriores representaçóes românticas. A partir dessa análise, ele constata que, em Shakespeare, há um tom mais ácido sobre o casamento do que o gênero ou mesmo suas peças demandavam. Levando em conta o contexto dramático das falas e das cenas citadas, o autor percebe que há, nos casais shakespearianos, uma incapacidade de felicidade no casamento que, em função dessa recorrência, poderia se relacionar com sua malsucedida experiência conjugal. Naquilo que extravasa o estilo e o gênero, é possível pensar a existência de uma marca da experiência pessoal e, até mesmo, uma denúncia contra o casamento. Uma segunda análise diz respeito aos diversos anacronismos presentes nas peças históricas. Ao tratar da Antiguidade - especialmente a romana -, Shakespeare constrói muito mais um quadro do seu mundo do que do antigo. Diversas das situaçôes criadas na Roma Antiga parecem se adequar muito mais à Londres do início do século XVII do que a cidades da Antiguidade. Aí, nestes anacronismos, Greenblatt encontra indícios da maneira como o autor se relacionava com o seu tempo presente.

Um segundo eixo de questóes e operaçóes analíticas que destaco de Como Shakespeare se tornou Shakespeare diz respeito ao uso da imaginação. No prefácio do livro, Greenblatt convida seus leitores a utilizarem a imaginação para conseguirem acompanhar os objetivos de seu livro. Uma vez 
que a documentaçáo que poderia oferecer dados para uma análise da produção da obra em questão e da vida de seu produtor é escassa, caberia ao historiador imaginar ligaçôes e vínculos perdidos. Dessa maneira, Greenblatt idealiza diversas cenas da vida de Shakespeare: imagina, a partir de uma canção utilizada em Rei Lear, a mãe do dramaturgo sussurrando esta mesma canção em seu ouvido e criando no menino um fascínio pela língua; imagina sua mãe guardando, aos olhos do filho e de maneira apressada, símbolos católicos logo após as novas regras religiosas impostas pelo Estado inglês; imagina, a partir de cenas de namoro das peças, Shakespeare namorando sua futura esposa.

Este uso da imaginação tem por objetivo, em diferentes momentos do livro, traçar as supostas motivaçóes que teriam levado o autor a escrever suas peças - mais uma vez vem à tona o esforço de historicizar e humanizar essa obra tantas vezes sacralizada. No capítulo 9 (Riso ao pé do cadafalso), Greenblatt trata de uma situação verídica que poderia ter levado Shakespeare a escrever $O$ mercador de Veneza: o momento da execução do dr. Lopez, um médico da rainha, conspirador e judeu no íntimo. A poucos momentos de sua execução em praça pública, ele teria declarado que amava a rainha da mesma forma que amava Jesus, o que levou as pessoas presentes a rirem imensamente. Greenblatt se pergunta, então, se Shakespeare não poderia estar presente naquela cena. Ele teria observado e pensado sobre estes risos, que se assemelhavam aos risos provocados por Marlowe em sua peça $O$ judeu de Malta. A partir disso, em $O$ mercador de Veneza, Shakespeare teria reproduzido estes risos e feito o público olhar para si mesmo, criando um efeito distinto daquele produzido pelo judeu de Marlowe. Uma cena verídica da execução de um traidor, uma peça de Marlowe, a reação do público, a criaçáo de $O$ mercador de Veneza são elementos utilizados por Greenblatt para tentar reconstruir o funcionamento da imaginação do dramaturgo, identificando o que a alimentava e como ele a trabalhava.

Como se percebe, a imaginação do analista tem um lugar de importância em Como Shakes- peare se tornou Shakespeare: ela é explicitamente assumida como um elemento de análise e busca uma cumplicidade com a imaginação do leitor. Cabe ressaltar, entretanto, que essa imaginação parte da evidente erudição do autor, especialmente em relação ao momento histórico trabalhado. Greenblatt, em diferentes momentos do livro, apresenta hábitos, locais, personagens, situaçóes dos ambientes frequentados por Shakespeare e, a partir daí, concebe cenas, diálogos, encontros, sempre controlados por este desenho mais amplo apresentado. Ou seja, a imaginaçáo e a suposição se dão a partir de detalhadas reconstruçôes de um ambiente, o que cria legitimidade para elas e impedem-nas de cair em anacronismos óbvios, sempre refutados pelo autor.

O uso da imaginação em Como Shakespeare se tornou Shakespeare evidencia uma necessária relação entre o historiador e a perda. $\mathrm{Na}$ "Nota ao leitor" do livro, Greenblatt adverte para as inúmeras ligaçôes que não podem ser feitas a partir do uso da documentação da época. Dessa forma, o livro é repleto de expressóes como "quase com certeza", "certamente", "provavelmente”, "poderia ter visto", "Shakespeare provavelmente conheceu", "talvez", "ele provavelmente deu um riso amarelo", "a história que provavelmente Will contou ao rei de armas", "ele com certeza deve ter se interessado pelo assunto", fazendo com que o autor se coloque - muito à vontade, é importante frisar - neste lugar de quem, apesar de toda a erudição, não pode pronunciar verdades absolutas.

De todo modo, o trabalho de Greenblatt acaba nos lembrando de que, mesmo sem deixar vestígios diretos na documentação, a trajetória de um escritor e a produçáo de sua obra se dão a partir dos encontros e relaçóes que ele estabelece, de pequenas situaçóes que ele vive, de pensamentos, impressóes, intuiçôes. No livro, são sugeridas cenas como a de Shakespeare aprendendo esgrima com algum vizinho, recitando textos na frente do espelho ou entrando num saláo londrino e sendo olhado por seus colegas escritores. Mesmo que essas cenas tenham um formato muito distinto do que efetivamente ocorreu no passado, mesmo que Shakespeare não tenha aprendido esgrima com um vizinho, elas 
nos lembram que uma vida como esta se constitui a partir destes encontros, destas conversas que não deixam registros documentais e que podem ser controladamente imaginadas a partir de um tipo de trabalho como o feito por Greenblatt.

Finalmente, um terceiro aspecto que ressalto é a forma como sua narrativa é constituída. Chama a atenção a ausência de notas do autor ao longo de todo o livro. Mesmo quando cita algum documento específico, Greenblatt não interrompe sua narrativa com notas. No final do texto, ele apresenta um longo comentário sobre a documentação utilizada nas "Notas bibliográficas", onde fica evidente a amplitude do material trabalhado para a produçáo do livro. Dessa forma, o autor opta por uma narrativa fluida em que diferentes tipos de documentos articulam-se de maneira dinâmica. O livro vai analisando e contrapondo recibos, testamentos, relatos de clérigos, relatos de viajantes, assim como trechos das peças de Shakespeare, cenas imaginadas por Greenblatt, sempre construindo ligaçôes - muitas vezes inesperadas, mas sempre muito coerentes e embasadas - que dáo conta de reconstituir a trajetória de Shakespeare e o mundo no qual ele se insere.

Outro aspecto notável ligado à narrativa é a articulação realizada entre a reconstruçáo de vida de Shakespeare e os textos de suas peças. Ao longo de todo o livro, o autor recorre às peças do dramaturgo para descrever momentos de sua vida, o que cria um tom ficcional para a biografia cabe destacar que Shakespeare é chamado, ao longo de quase todo o livro, de Will, o que gera uma intimidade com o leitor própria dos personagens literários - ou, visto por outro lado, cria um tom verídico para os personagens teatrais. Cria-se um tipo vertigem que faz com que as falas dos personagens shakespearianos dialoguem, a todo momento, com a construção de sua biografia. Até mesmo pequenos recursos narrativos contribuem com esse movimento de quebra de fronteiras entre a análise biográfica e as peças, como o uso de pequenas expressóes utilizadas por personagens para começar uma frase. Uma expressão usada pelo personagem Horácio, por exemplo, dá início a toda uma discussão sobre um momento específico da vida de seu criador.

Ao final da leitura, é interessante retornar ao prefácio do livro, onde Greenblatt lembra que, desde o século XIX, já existiam boas biografias de Shakespeare muito bem documentadas. Surge, então, a questão: por que se produzir uma nova biografia? Uma resposta pode ser sugerida: para se construir esta forma de narrar específica. O livro parece lançar uma série de questôes inéditas à trajetória individual do dramaturgo, mas também utiliza, para escrever essa trajetória, uma dinâmica narrativa, um jogo entre vida e obra, documento e cena imaginada que certamente não está presente nesses tantos outros trabalhos sobre a vida do bardo. Shakespeare, como se sabe, reescrevia antigas histórias para dar-lhes novos sentidos a partir de seu extremo domínio da linguagem. Fica a impressão de que Greenblatt inspirou-se nessa atitude de Shakespeare para reescrever sua biografia. 